\title{
ARSITEKTUR SISTEM INFORMASI EMERGENCY HEALTH CARD RUMAH SAKIT BERBASIS CLOUD COMPUTINGMENGGUNAKAN UNIFIED SOFTWARE DEVELOPMENT PROCESS (USDP)
}

\author{
Mukhsin \\ Fakultas Teknik Universitas Wiralodra, Jln. Ir. H. Juanda Km 3 Indramayu, Jawa barat, \\ mukhsin_qrpratama@yahoo.com
}

\begin{abstract}
ABSTRAK
Sistem informasi Emergency Health Cardterpadu berbasis cloud computingmerupakan salah satu pemanfaatan teknologi yang menggunakan Smardcard Usb Drive sebagai web monitoring yang digunakan untuk pengeleloaan terhadap data pasien dan rekam medis di rumah sakit.Proses Perancangan Arsitektur Sistem dimaksudkan untuk membantu setiap rumah sakit didalam mengelola data pasien, ketika seorang pasien berobat ke rumah sakit yang berbeda tidak harus ada pencatatan ulang tetapi dengan menggunakan teknologi Smardcard Usb Drive dan database yang disimpan secara cloud computing, sistem sudah terintegrasi dengan seluruh rumah sakit.Metode Perancangan Arsitektur Sistem Informasi yang digunakan adalah Metode Unified Software Development Process(USDP) dimana metode ini digunakan untuk membangun sebuah kerangka kerja (framework) yang digunakan untuk pengembangan aplikasi. Proses pengembangan perangkat lunak yang dibagi dalam beberapa fase, dimana setiap fase tersebut dilakukan beberapa tahap kerja yang dilakukan secara berulang.Proses penelitian ini dilakukan dengan merancang arsitektur sistem informasi terhadap data pasien dan rekam medis kemudian sistem ini memiliki kemampuan untuk memonitoring perkembangan kesehatan pasien walaupun dari rumah sakit yang berbeda-beda secara online.
\end{abstract}

Kata Kunci: Sistem Informasi, Arsitektur Sistem, Emergency Health Card, Cloud Computing, SmardCard Usb Drive, UnifiedSoftware Development Process, framework.

\begin{abstract}
Integrated information system on Emergency Health Card based on Cloud Computing is one of technology utilization which uses Smartcard USB Drive as a web monitoring used to manage patients' data and medical record in hospitals.Architectural System Planning process is meant to help every hospital in managing patient' data when a patient who gets medication in different hospital does not need to do reregistration but by using Smartcard USB Drive and using database in cloud computing, their data has already been integrated in all hospitals.Information system of architectural planning method uses Unified Software Development Process method (USDP). This method is used to establish a framework which is used to develop application. Software development is divided into some phases where in each phase is done some work stages repeatedly.This research process is done by designing architectural information system on patients' data and medical record. Then, this system has its own ability to monitor patients' health development even from different hospital in online way.
\end{abstract}

Keywords : $\quad$ Information System, Architectural System,Emergency Health Card, Cloud Computing, Smartcard USB Drive, UnifiedSoftware Development Process, framework.

\section{PENDAHULUAN}

Pemanfaatan teknologi informasi sebagai jawaban terhadap semakin tingginyatuntutan masyarakat akan peningkatan kualitas layanan publik semakin meluas diberbagai sektor termasuk di lembaga penyedia layanan kesehatan seperti rumah sakit.Hal ini ditandai dengan maraknya pengimplementasian solusi teknologi informasi baikdi rumah sakit milik pemerintah maupun rumah sakit yang dikelola pihak swasta.

Penggunaan software aplikasi di rumah sakit seringkaliditerapkan secara parsial di setiap unit 
organisasi dimana aplikasi-aplikasi ini tidaksaling compatible antara satu dengan yang lainnya. Aplikasi-aplikasi ini umumnyabergantung pada platform dan sistem operasi tertentu yang menyulitkan prosesintegrasi dan pengembangan sistem aplikasi selanjutnya.

Salah satu pemanfaatan teknologi informasi yaitu adanya sistem informasi Emergency Health Carddengan berbasis Cloud Computing.Sistem ini memanfaatkan teknologi card atau kartu yang dapat dihubungkan melalui port usb kemudian di integrasikan dengan sistem informasi untuk dapat melihat setiap data pasien baik alamat,data keluarga,historical view kesehatan pasien meliputi penyakit, alergi baik terhadap obat atau makanan tertentu, rumah sakit yang pernah dikunjungi setiap pasien untuk berobat, analisa terhadap penyakit dari setiap dokter atau rumah sakit. Sehingga hal ini akan membantu pihak rumah sakit didalam memberikan keputusan secara tepat terhadap setiap penyakit yang diderita oleh pasien tanpa harus memasukan datadata pasien kembali.

\section{Arsitektur Sistem Informasi}

Arsitektur informasi (atau arsitektur teknologi inforrnasi, arsitektur sistem informasi, infrastruktur teknologi informasi) adalah suatu pemetaan atau rencana kebutuhan-kebutuhan informasi di dalam suatu organisasi (Turban, McLean, Wetherbe, 1999). Arsitektur ini berguna sebagai penuntun bagi operasi sekarang atau menjadi cetak-biru (blueprint) untuk arahan di masa mendatang. Tujuan dari arsitektur ini adalah agar bagian teknologi informasi memenuhi kebutuhan-kebutuhan bisnis strategis organisasi. Oleh karena itu, arsitektur informasi memadukan kebutuhan informasi, komponen sistem informasi, dan teknologi pendukung. [3]

Sebuah arsitektur informasi yang detail berisi perencanaan yang digunakan untuk menjawab pertanyaan-pertanyaan berikut (Alter, 1992) :

1. Data apa yang akan dikumpulkan?

2. Di mana dan bagaimana data dikumpulkan?

3. Bagaimana cara mengirimkan data?

4. Di mana data akan disimpan?

5. Aplikasi-aplikasi (program) apa yang akan menggunakan data dan bagaimana aplikasiaplikasi tersebut dihubungkan sebagai sebuah sistern yang utuh?
Arsitektur informasi menggunakan arsitektur teknologi yang dapat dibedakan menjadi tiga macam, yaitu tersentralisasi (centralized), desentralisasi (decentralized), dan client/server.[3]

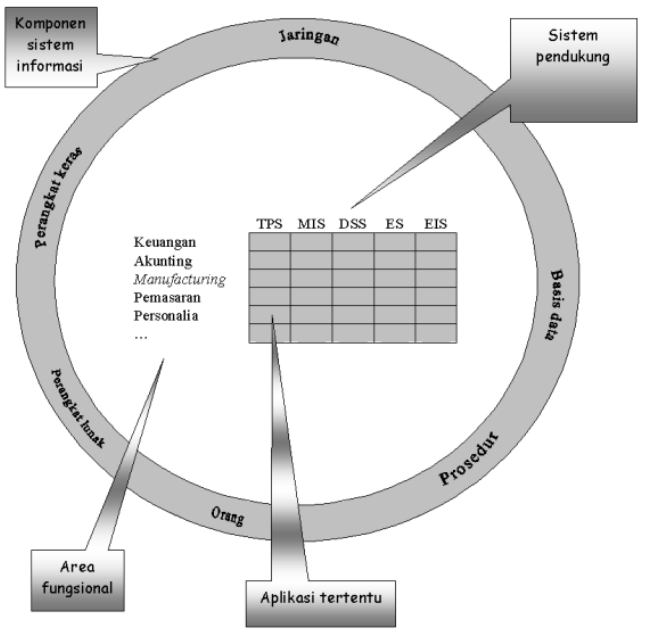

Gambar 1. Skema Arsitektur Informasi [3]

\section{Sistem InformasiEmergency Health Card}

Sistem informasi Emergency Health Card adalah sebuah sistem informasi yang menggunakan teknologi hardware smartcardyang dihubungkan melalui port usb pada PC (personal computer), laptop, Notebook atau perangkat lain yang mendukung smarth card,sistem informasi Emergency Health Card ini diharapkanbisa memberikan informasi data mengenai seorang pasien, dapat memberikan informasi mengenai data alamat pasien, history atau riwayat kesehatan pasien.Manfaatyang dapat diperoleh dalam menggunakan Emergency Health Cardadalah:

" The key is to save the person's life, stabilize patient, learn about their conditions as fast as possible and apply proper emergency procedures and or medications. Injured person is in pain, in shock, can't cooperate, and or maybe even out of conscious. In moments like that EMS needs all the help they can possibly get! Other than traumatic injuries that are self evident, non traumatic injuries require much more information to achieve a more desired higher quality treatment. World Health Card software suite has many featuresfor EMS (Emergency Medical Services)'”[9]

Smartcard merupakan salah satu pengembangan teknologi dibidang informasi 
yaitu sebagai perangkat terintegrasi dengan kemampuan penyimpanan data dan pengolahan data. Penggunaan smartcard dibidang pelayanan kesehatan semakin populer karena kapasitas dan lingkup kemampuannya yang terus meningkat. Efisiensi penggunaan dengan akses ke fasilitas data yang mudah dan cepat terutama dalam hal sistem keamanan menjadikan sistem ini sangat diminati.Berdasarkan perbandingan beberapa teknologi sistem smartcard kesehatan di luar negeri yang disesuaikan dengan kondisi sistem rekam medis di Indonesia, diperoleh hasil bahwa sistem smartcard kesehatan di luar negeri dapat memenuhi hampir sebagian besar kebutuhan sistem rekam medis di Indonesia. (Sariasih, 1999) [1]

Dari beberapa manfaat tentang pemanfaatan teknologi smartcarduntuk Emergency Health Card, penulis dapat membuat kesimpulan Emergency Health Card merupakan pemanfaatan teknologi informasi dalam memberikan kemudahan dari segi waktu, data yang diperlukan oleh pihak rumah sakit atau yang terkait dalam menangani pasien secara tepat, akurat, terukur dan terarah.

\section{Cloud Computing}

Istilah Cloud atau Awan ini sebenarnya penggambaran dari teknologi internet itu sendiri. Seringkali kita melihat suatu diagram internet dicakup atau berada di dalam suatu simbol yang berbentuk awan. Teknologi cloud computing ini memang cukup popular dan mulai banyak diminati serta dimanfaatkan di segala bidang seperti untuk media penyimpanan, industri, pengembangan industri dan masih banyak lagi.

Cloud computing biasanya menjalankan suatu program tanpa melakukan proses instalasi terlebih dahulu. Tidak hanya itu pengguna juga dapat mengakses data - data yang ada di dalam aplikasi tersebut dimana pun dan kapan pun. Salah satu contohnya adalah dalam bentuk media penyimpanan seperti Google Drive, Drop Box, ataupun bentuk aplikasi lain seperti Gmail, Yahoo Mail, Windows Azure, Amazon dan lain lain. Namun perlu diingat juga tidak semua aplikasi yang terkoneksi internet menerapkan cloud computing juga.Dengan cara kerja cloud computing seperti ini maka prosesnya akan lebih cepat serta akurat. Cara kerja sistem cloud ini juga lebih menjamin dari segi keamanan, oleh karena pemanfaatan cloud computing memang lebih banyak dilakukan dalam hal media penyimpanan. Penggunaan perangkat harddisk ataupun flashdisk memang banyak memunculkan resiko. Hal itulah yang melatarbelakangi kemunculan Google Drive ataupun Drop Box meskipun kapasitasnya masih sangat terbatas. [4]

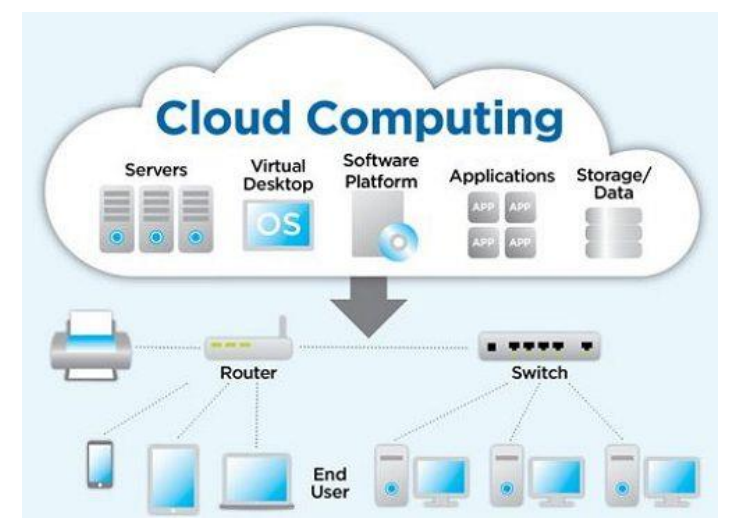

Gambar 2. Cara Kerja Cloud Computing[4]

Banyaknya perusahaan yang mulai menggunakan teknologi cloud computing membuktikan bahwa pengaruh yang ditimbulkan cukup besar. Bagi sebagian besar pengguna memang menilai kinerja dari cloud computing ini cukup memuaskan. Namun wajib diketahui bahwa suatu hal yang dianggap menguntungkan tidak menutup kemungkinan juga masih menyimpan kekurangan tersendiri, termasuk juga pada cloud computing.

\section{METODE PENELITIAN}

Unified Software Development Process(USDP)merupakan metodologi untuk pengembangan perangkat lunak, utamanya perangkat lunak yang berorientasi objek. Metodologi ini pertema kali diperkenalkan oleh Rational Team, yang pada perkembangan selanjutnya metodologi ini disempurnakan kembali menjadi metodologi baru yang bernama Rational Unified Process (RUP), yang sekaligus menjadi cikal bakal terbentuknya kurang lebih tujuh metodologi lainnya.[2]

Proses yang terjadi di USDP tidaklah sesederhana jika dibandingkan dengan metodologi klasik, sepertiwaterfalldaniterative model. Hal ini dikarenakan USDP lebih digunakan untuk membangun sebuah kerangka kerja (framework) yang bisa dikustomisasi untuk kepentingan organisasi dan proyek yang lebih spesifik. Dengan framework bisa menghasilkan beragam aplikasi karena adanya konsep coding 
reuse, dimana coding yang sama bisa dipakai untuk keperluan aplikasi sejenis.[6]

USDP tidak mengikuti siklus hidup pengembangan perangkat lunak tradisional (waterfall model) melainkan mengadopsi pendekatan iterative dengan 4 fase utama. Setiap fase menggambarkan penekanan pada kegiatan yang penting pada pengembangan sistem. Fasefase tersebut digambarkan dalam bentuk aliran kerja (workflows) dimana aliran tersebut merupakan serangkaian aktifitas.[7]

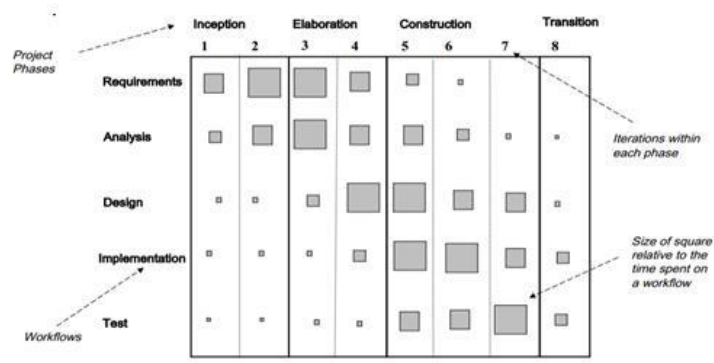

Gambar 3. Fase dan Workflow USDP [5]

Metodologi Arsitektur Sistem Informasi Emergency Health Cardyang dilakukan dalam penelitian ini adalah metodologi USDP yang merancang aplikasi lebih terencana.

Untuk memudahkan dalam penyusunan rencana perancangan perangkat lunak dengan menggunakan USDP (Unified Software Development Process), dimana pada model ini perencanaan global dari pengembangan sistem informasi akan dipecah menjadi beberapa fase yang dilakukan secara iterative dan incremental.[8]

1. Fase Permulaan (Inception Phase)

Yaitu tahap dimana konsep, lingkup dan visi dari produk sedang dibentuk, sampai ke tingkat yang memungkinkan untuk diproses.Pada alur kerja ini menjelaskan proses bisnis dari Sistem Informasi Emergency Health Card dilihat dari visi dan misi Rumah sakit sehingga terbentuk tujuan untuk dilakukan Arsitektur Sistem Informasi Emergency Health Card yang diharapkan dapat menunjang terhadap proses bisnis yang sedang berjalan, selanjutnya didalam Fase Permulaan sudah menentukan kebutuhan Infrastruktur Jaringan Komputer, Kebutuhan Perangkat Keras baik server maupun client.

2. Fase Elaboration (Elaboration Phase)

Pada tahap ini semua sumber daya, aktivitas dan hasil kerja diidentifikasi dan
direncanakan.Selama tahap ini arsitektur operasioanal sistem mulai dibangun.Menyempurnakanruang lingkup sistem dan permintaan user dalam hal ini harus memperjelas kebutuhan fungsionalitas dari sistem aplikasi yang akan digunakan didalam Emergency Health Card yang digambarkan dalam BPMN (Business Process Modelling Notation).Menetapkan apa yang dibangun serta membuat arsitektur yang dinamis dalam hal ini penggambaran dilakukan dengan pemodelan use case dan class diagram, membuat Arsitektur Sistem secara garis besar yang dimodelkan dengan sequence diagramkemudian uji kelayakan terhadap Arsitektur Sistem Informasi Emergency Health Card dalam hal ini dilakukan penggambaran component diagram.Kebutuhandidalam penerapan perancangan Arsitektur Emergency Health Card di rumah sakit yang dimodelkan kembali dalam model deployment diagram.

3. Fase Konstruksi (Construction Phase)

Tahap dimana perancangan mulai diimplementasikan secara bertahap dalam beberapa iterasi.Pemeriksaanterhadap kegiatan perancangan agar sesuai dengan proses bisnis yang dirancang. Menentukan arsitektur sistem Cloud Computing sebagai server yang nantinya akan digunakan, kemudian menentukan arsitektur jaringan komputer dengan pemanfaatan teknologi Smart Card Usb Drive dan menentukan arsitektur teknologi web yang digunakan untuk membuat sistem informasi Emergency Health Card di rumah sakit.

Dalam setiap fase tersebut terdapat 6 tahap kerja (workflows) yang harus dilakukan yaitu :[5]

1. Requirement capture and modeling, Pada tahap ini bertujuan untuk mengumpulkan bahan-bahan yang diperlukan untuk pengembangan sistem dan memodelkan bahan-bahan tersebut. Diagram UML yang dibuat adalah use case dan activity diagram.

2. Requirementsadalah proses analisis kebutuhan sistem berdasarkan daftar kebutuhan yang sudah dikumpulkan pada aktivitas sebelumnya . Biasanya bentuk yang digunakan adalah Use Case. Use Case adalah serangkaian kegiatan yang menggambarkan bagaimana user (juga disebut actor) berkomunikasi dengan sistem. 
3. Analysis, tujuannya memberikan deskripsi dan model yang lebih jelas (berdasarkan gambaran pada usecase). Dalam tahap ini usecaseakan dianalisa secara seksama, setiap detail akan dijabarkan lebih lanjut, setiap relasi antar objek akan diidentifikasi, juga karakteristik statik dan dinamik dari tiap class akan diidentifikasi.

4. Design, dalam tahap ini model analisis akan disempurnakan dan diadaptasikan dalam platform tertentu yang spesifik (compiler, hardware, sistem operasi, basis data dan sebagainya).

5. Implementation, tahap ini mentransformasikan model desain menjadi suatu program yang akan dimodifikasi dalam bahasa pemrograman,

6. Test, tujuan dari tahap ini adalah melakukan verifikasi dan perbaikan kinerja software, seperti menguji apakah sistem menghasilkan output yang tepat untuk setiap input yang masuk.

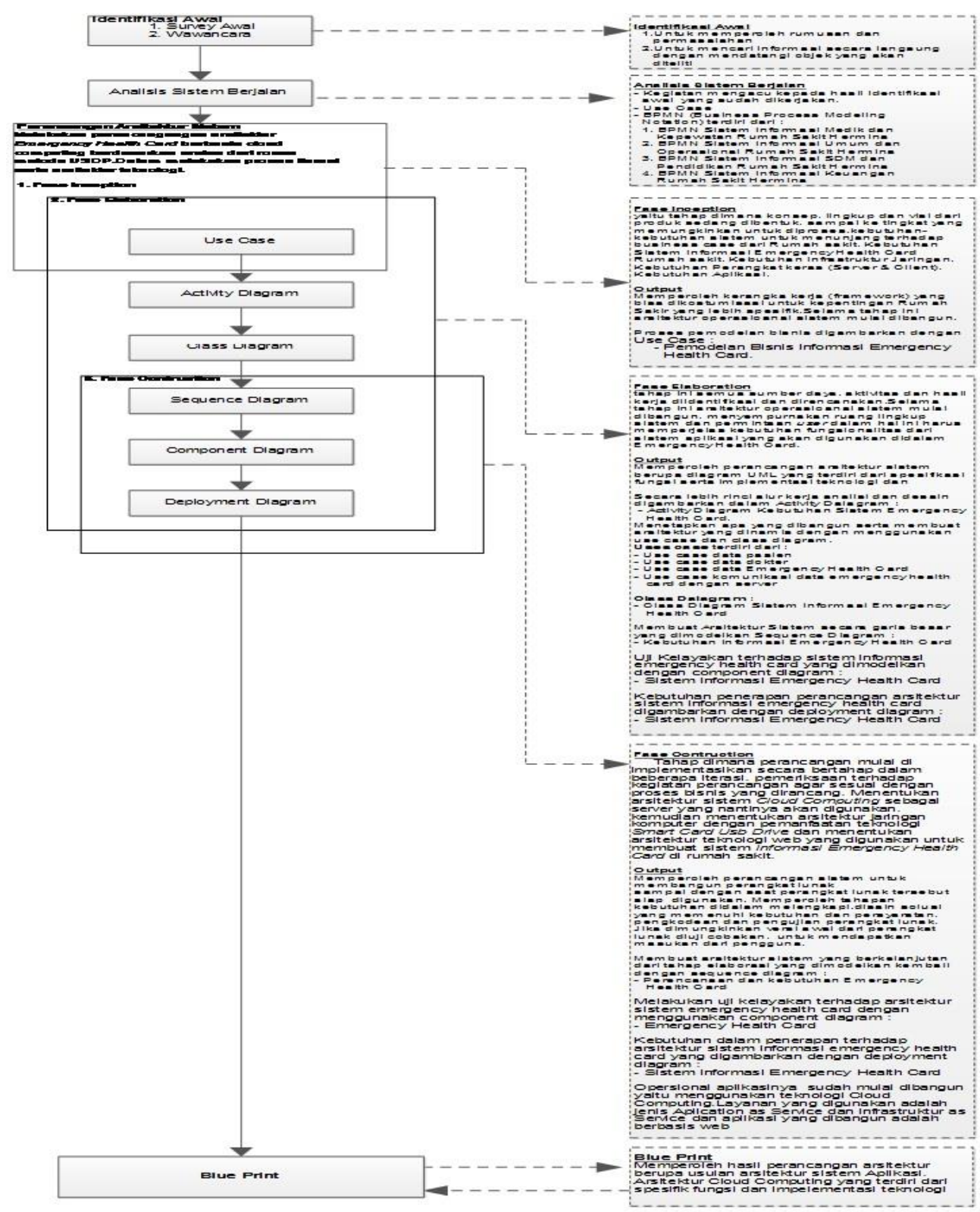

Gambar 4. Metodologi Perancangan Arsitektur

\section{HASIL DAN PEMBAHASAN}

Arsitektur sistem informasi
Health Card merupakan alat bantu aplikasi didalam mengelola rekam medis pasien di rumah 
sakit secara cepat, tepat, akurat, efektif dan efesien yang didukung Sistem Jaringan Komputer berbasis cloud computing sehingga penyimpanan database menjadi terpusat.Kegiatan didalam perancangan Arsitektur Sistem Emergency Health Card harus memberikan manfaat didalam mengelola rekam medis setiap pasien.

Didalam menginplementasikan suatu Sistem Informasi atau aplikasi sangat di tentukan oleh 4 (empat) faktor utama sebagai Kunci Sukses dalam mengimplementasikan Teknologi Sistem Informasi Emergency Health Card, yaitu :

1. Faktor Software

Software yang dibuat harus dapat disesuaikan dengan hasil analisis dan perancangan yang dilakukan.Beberapa faktor yang menjadi hal yang penting didalam membangun sebuah software yaitu fleksible, Mudah digunakan (user friendly), aman (security), integrasi dan dapat di perbaharui atau diupdate apabila terjadi penambahan atau perubahan fasilitas pada software yang dibuat.

2. Faktor Hardware

Software yang dibuat harus mendukung pada hardware yang digunakan dimana spesifikasi Hardware yang dibutuhkan dengan software yang dibuat harus sesuai karena salah satu keberhasilan didalam mengimplementasikan software adalah kelengkapan perangkat keras atau hardware dan sekuritas pada hardware tersebut.

3. Faktor Jaringan (Networking)

Software yang dibangun berbasis web based sehingga sangat bergantung pada sistem jaringan terutama jaringan internet. Pada saat ini perusahaan sudah memiliki jaringan komputer (WAN) yang sudah terintegrasi antara pusat dengan seluruh cabang-cabang perusahaan,dilihat dari faktor jaringan perusahaan sudah memiliki fasilitas yang baik pada saat software atau sistem informasi web based ini digunakan.

4. Faktor Sumber Daya Manusia (SDM)

Software tidak akan berfungsi atau berjalan dengan baik jika tidak ada sumber daya manusia yang akan menggunakannya.Sehingga diperlukan sumber daya manusia yang dapat bertanggungjawab terhadap penggunaan atau berjalannya software.

Ruang Lingkup perancangan arsitektur Sistem Informasi Emergency Healh Card di Rumah Sakit ini meliputi modul yang terdiri dari (1) Data Pasien, (2) Data Dokter, (3) Riwayat Medis, (4) Data Card, (5) Komunikasi, (6) Bantuan, dari semua modul tersebut hasilnya dibuat dalam software requirement specification.

\section{Fase Permulaan (Inception Phase),}

Tahap konsep, lingkup dan visi dari produk sedang dibentuk, sampai ke tingkat yang memungkinkan untuk diproses. Selama tahap ini semua alternative solusi harus dikemukakan dan diuji melalui uji kelayakan.

Pada gambar 5 dapat dijelaskan secara umum proses Sistem Informasi Emergency Health Card, untuk penyimpanan sistem ini akan dikelola oleh bagian Pendaftaran dan rekam medis dari masing-masing rumah sakit ,setiap rumah sakit dapat mengakses sistem informasi Emergency Health Card ini.

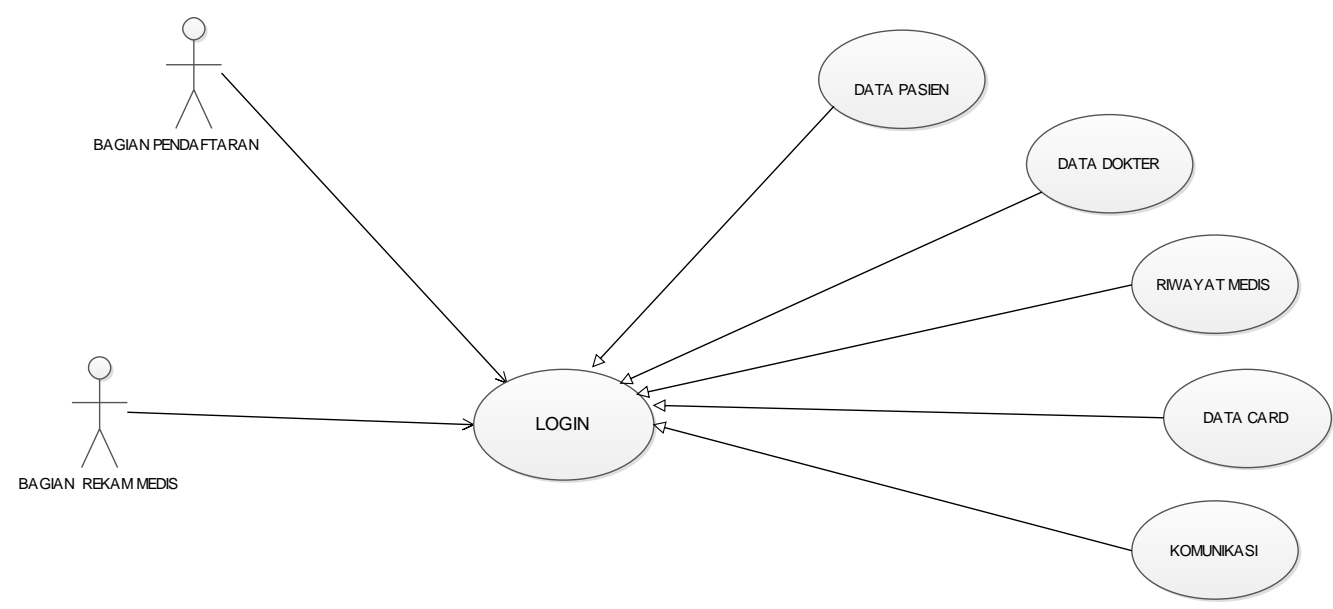

Gambar 5 Use Case Pemodelan Bisnis Informasi Emergency Health Card

2. Fase Elaboration (Elaboration Phase),

Tahap semua sumber daya, aktivitas dan 
hasil kerja diidentifikasi dan direncanakan.Selama tahap ini arsitektur operasioanal sistem mulai dibangun.

Berikut ini adalah identifikasi actor yang terlibat:

Tabel 1.Actor Sistem

\begin{tabular}{|c|c|c|}
\hline NO & ACTORS & DESKRIPSI \\
\hline 1. & Pendaftaran & $\begin{array}{l}\text { Useryang diberi hak } \\
\text { untuk melakukan input } \\
\text { data pendaftaran pasien } \\
\text { dan mengalokasikan ke } \\
\text { bagian dokter yang } \\
\text { menangani } \\
\text { tersebut. }\end{array}$ \\
\hline 2 & $\begin{array}{l}\text { Rekam } \\
\text { Medis }\end{array}$ & $\begin{array}{l}\text { User yang melakukan } \\
\text { rekam atau penyimpanan } \\
\text { medis atau kesehatan } \\
\text { setiap pasien yang datang } \\
\text { ke rumah sakit }\end{array}$ \\
\hline
\end{tabular}

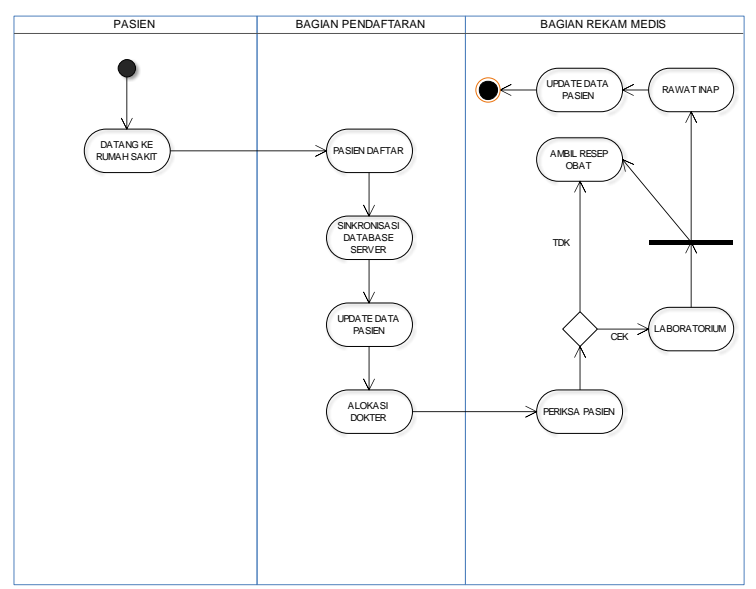

Gambar 6. Activity Diagram kebutuhan sistem Emergency Health Card

Tujuan fase elaborasi adalah:

1. Membuat dasar arsitektur sistem yang dapat dijalankan

2. Membuat perancangan rinci untuk fase kontruksi

3. Memformulasikan sumber daya yang akan terlibat.

4. Menyempurnakan penetapan resiko

5. Menetapkan $80 \%$ requirement fungsional dalam bentuk use case.

Penggambaran dilakukan secara garis besar untuk Sistem Informasi Emergency Health Carddi Rumah Sakit.

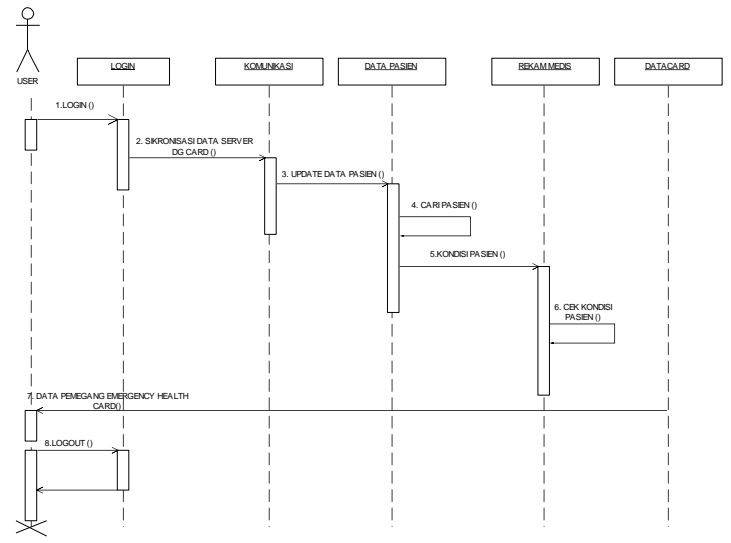

Gambar 7. Sequence DiagramKebutuhan Emergency Health Card

\section{Fase Konstruksi (Construction Phase),}

Tahap perancangan mulai diimplementasikan secara bertahap dalam beberapa iterasi.

Tujuan dari fase kontruksi adalah:

1. Menyelesaikan indetifikasi, deskripsi dan realisasi use-case

2. Menyelesaikan analisis, perancangan, implementasi dan pengujian (test)

3. Memelihara integritas arsitektur system

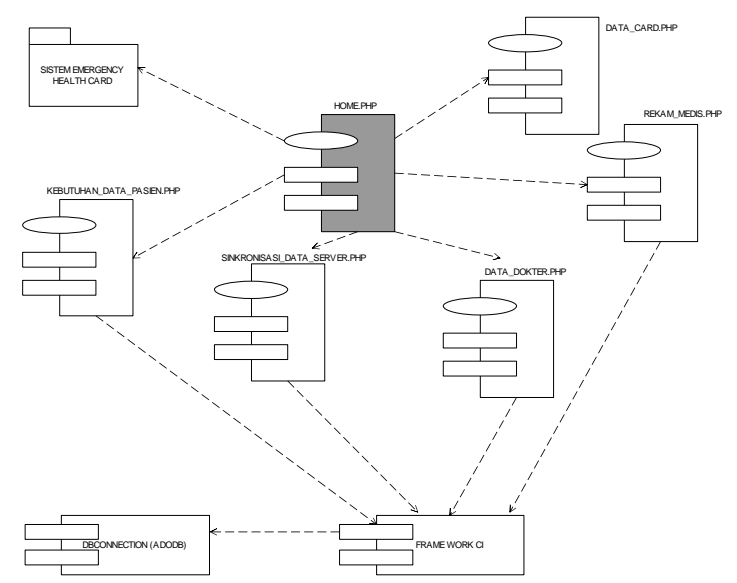

Gambar 8. Component Diagram Sistem Informasi Emergency Health Card

\section{Arsitektur Cloud computing}

Dalam sistem Emergency Health Card ini untuk operasional aplikasinyamenggunakan teknologi cloud computing. Sedangkan layanan yang digunakan adalahjenis Aplication as Service dan Infrastruktur as Service.Dan aplikasi yang dibangunadalah berbasis web.

Sistem Emergency Health Card berbasis cloud computing ini terdapat beberapa lapisan 
dan komponen yang salingketergantuan satu sama lainnya dan mempunyai fungsi berbeda antar lapisan dan salingmelengkapi.

Berikut adalah lapisan dalam arsitektur cloud computing sistem Emergency Health Card:
1. Lapisan Virtual Infrastuktur.

2. Lapisan Virtual Aplikasi.

3. Lapisan Service Manajemen.

4. Lapisan Pelanggan (End User)

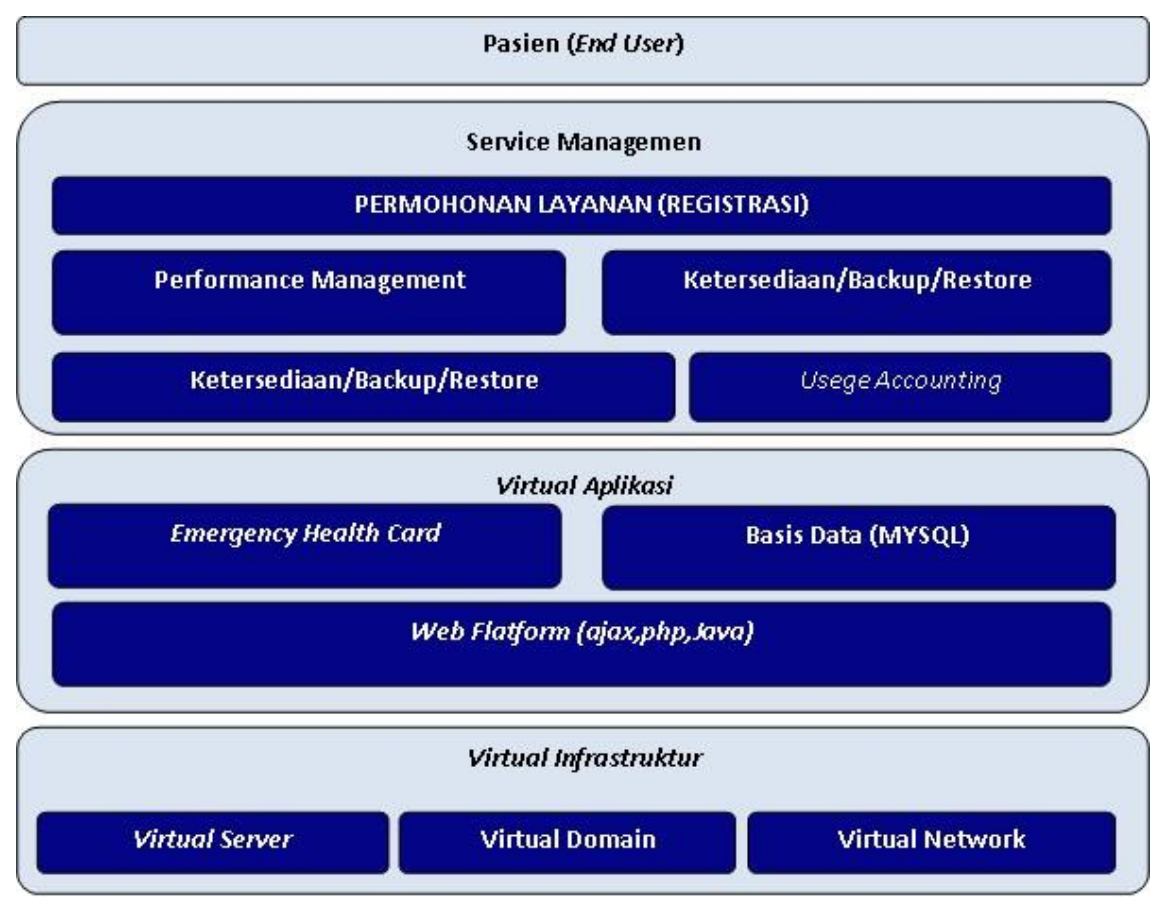

Gambar 9. Arsitektur Cloud Computing

\section{Arsitektur Basis data}

Basis data adalah tempat untuk menyimpan berkas-berkas mengenaioperasional data diri pasien dan rekam medisnya seperti data tempat tinggal, data historical view atau catatan kesehatan dari setiap rumah sakit dimana pasien pernah berobat.Basis data yang dapat digunakan untuk sistem emergency health card ini adalahMysql, MSSQL dan oracle. Sehingga dapat memberi pilihan kepada para rumah sakitsesuai dengan kebutuhan masing-masing.

Untuk basis data antara rumah sakityang satu dengan rumah sakit yang lain terpisah dalam satu database yang berbedaseperti terlihat pada gambar 11, sehingga dapat memudahkan kepada para penggunauntuk memanajenya sendiri seperti proses backup dan restore database.

Sedangkanuntuk server database ini menggunakan virtual operating sistem sehingga bisamenggunakan sistem operasi linux ataupun windows sehingga bisa menggunakandatabase MsSql yang berjalan di windows ataupun menggunakan MySql atau oracleyang dapat beroperasi di sistem operasi linux.

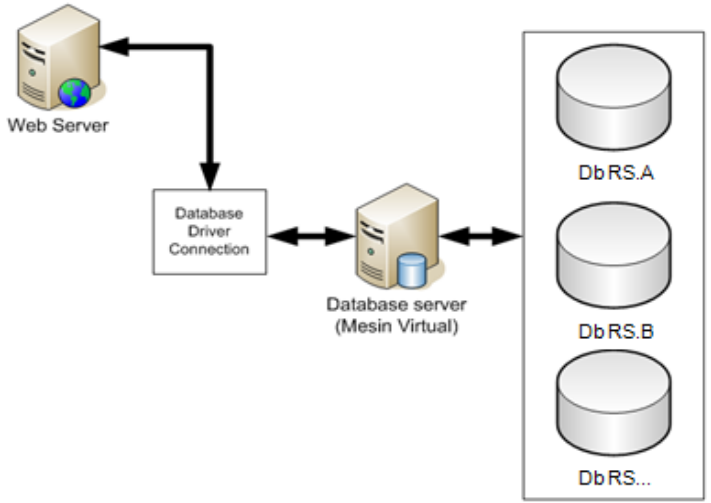

Gambar 10. Arsitektur Database

\section{Arsitektur Jaringan}

Dalam mengintegrasikan sistem emergency health card di rumah sakit diperlukan infrastruktur jaringan yang bertujuan untuk memudahkan komunikasi data antar card usb driver dengan rumah sakit.

Bentuk hubungan yang diperlukan untuk komputer-komputer di rumah sakit yang tersebar harus menggunakan Wide Area Network (WAN), yaitu suatu bentuk jaringan komputer tanpa kabel yang mempunyai ruang lingkupgeografis yang 
luas.

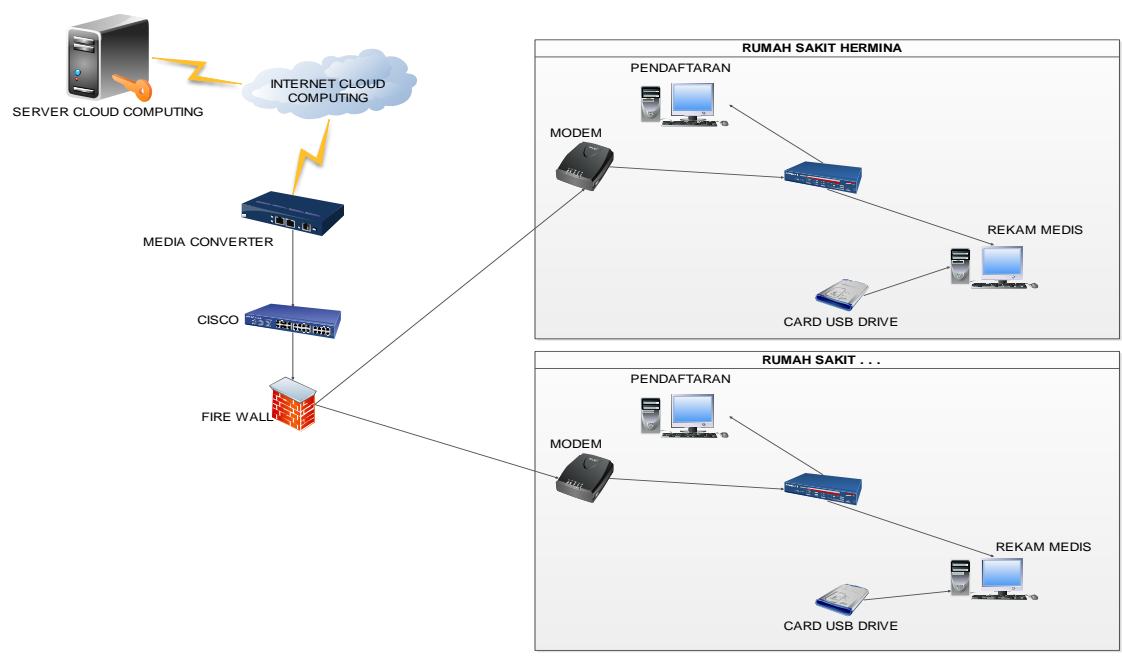

Gambar 11.Arsitektur Jaringan SistemEmergency Health Card

\section{Arisitektur Teknologi Web}

Dalam penelitian ini penulis menggunakan teknologi berbasis web didalam membuat sistem ini, dimana teknologi web tersebut menggabungkan teknolgi dari HTML, CSS, PHP, Javascript dan AJAX dengan alasan sebagai berikut:

1. Multiplafform didalam melakukan pengaksesan terhadap aplikasi berbasis web.

2. Kemudahan didalam melakukan implementasi

3. Kemudahan didalam melakukan pertukaran data dengan menggunakan teknologi web server.
4. Kemudahan didalam melakukan akses data yang dapat dilakukan dimana saja (fleksibilitas)

5. Adanya inovasi teknologi disisi pengguna (AJAX) sehingga pengaksesan bisa lebih cepat.

Arsitektur Teknologi Web ini menggunakan konsep Three-Tier adanya lapisan presentasi, lapisan data, untuk implementasinya dengan menggunakan framework CI (CodeIgniter).

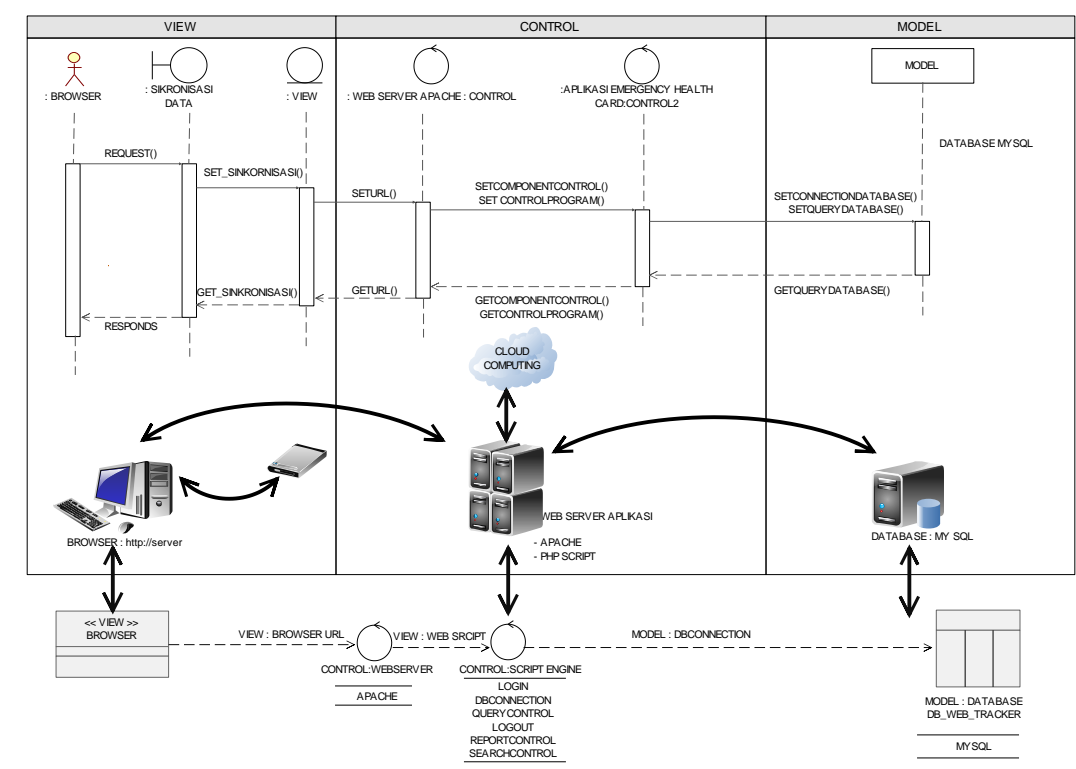

Gambar 12. Implementasi Arsitektur CI (CodeIgniter) Sistem Informasi Emergency Health Card

Dalam melakukan implementasi three-tier yang menggunakan 3 komponen utama yaitu ini menggunakan framework CI (CodeIgniter) Model, View, dan Controller.Dalam perancangan 
Sistem Informasi Web Based Tracker ini menggunakan database server MySQL dimana design database yang disesuaikan dengan Class
Diagram yang dirancang seperti pada gambar berikut ini.

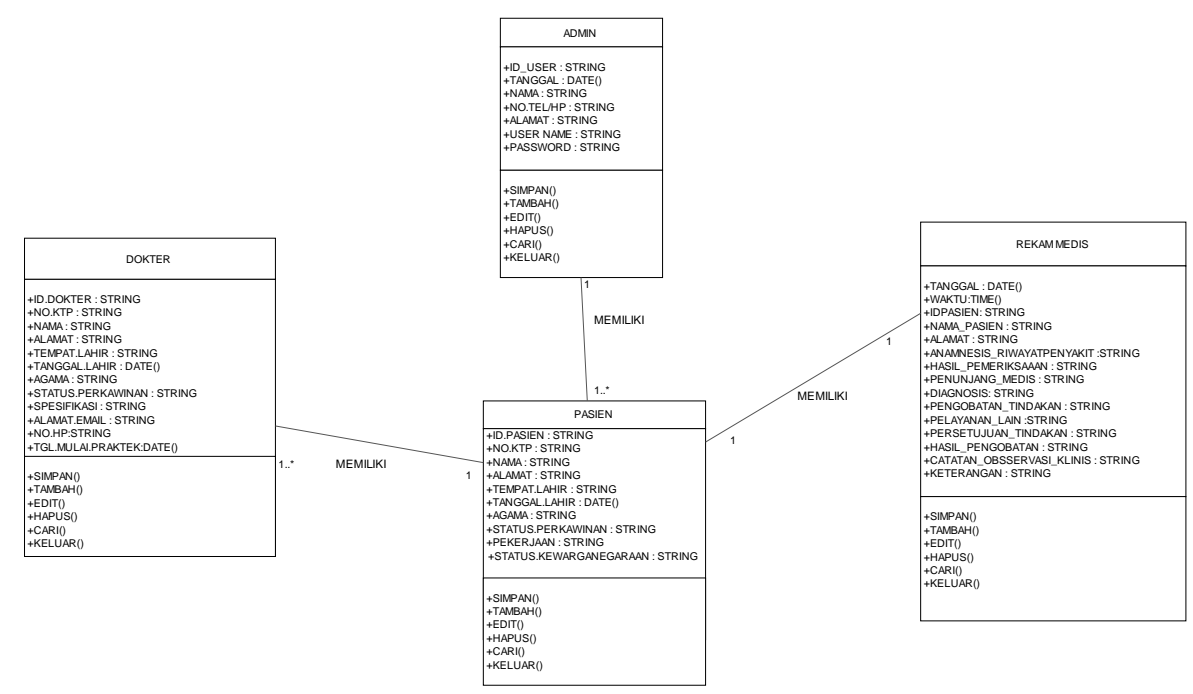

Gambar 13. Perancangan Basis Data

\section{Antarmuka pengguna (user)}

Pengguna yang akan menggunakan Sistem Informasi Emergency Health Card ini adalah yang berada dalam lingkungan rumah sakit dimana user ini dibagi menjadi beberapa level yaitu :

\section{Administrator \\ Administrator adalah superuser yang dapat mengelola semua Sistem Aplikasi}

2. Staf Pendaftaran

Pencatatan nama pasien, laporan volume kunjungan pasien dan pencatatan pembayaran.

3. Staf Rekam Medis

Untuk mencatat semua laporan transaksi layanan rekam medic, data kesehatan, tindakan, obat, catatan medis, operasi, hasil laboratorium yang telah dilakukan terhadap pasien selama dirawat di rumah sakit, dan data akan tersentralisasi dalam sebuah database server

Dengan menggunakan aplikasi browser (Internet Explorer, Modzilla Firefox, Opera, Google Chrome dsb) untuk dapat mengakses aplikasi Sistem Informasi Emergency Health Card Setelah menuliskan alamat aplikasi tersebut yang disimpan pada server maka akan muncul menulogin, menu login ini merupakan suatu form isian yang berisi partner id, username dan password untuk dapat mengakses data dan informasi pada aplikasi Sistem Informasi Emergency Health Card. Menu Login ini berfungsi untuk membatasi data-data user yang berhak mengakses data dan informasi pada aplikasi. Data-data user tersebut sebelumnya harus didaftarkan terlebih dahulu olehAdministrator rumah sakit yang sudah ditunjuk.

\section{KESIMPULAN}

Dari penelitian ini akhirnya penulis dapat memberikan kesimpulan sebagai berikut:

1. Perancangan arsitektur sistem yang diperlukan untuk Sistem Emergency Health Card terpadu untuk rumah sakitberbasis Cloud Computing adalah sebagai berikut:

a. Hasil dari Perancangan yang dilakukan dengan metodologi USDP (Unified Software Development Process) ini adalah menghasilkan usulan arsitektur sistem berbentuk software requirement specification yang diharapkan sesuai dengan keinginan rumah sakit didalam mengelola data pasien.

b. Pengembangan Arsitektur Teknologi berbasis web sebagai solusi untuk melakukan integrasi satu rumah sakit dengan rumah sakit lainnya, diusulkan untuk mempercepat waktu didalam pengelolaan pendaftaran dan rekam medis pasien dari rumah sakit yang berbeda dan menentukan secara tepat analisa penyakit dari setiap pasien. 
c. Arsitektur Teknologi Three Tier, dimana dalam implementasinya menggunakan arsitektur three tier yang menggunakan framework CI (Codeigneter) yang berbasis PHP dengan model MVC (Model-ViewControl) yang dapat membagi kebutuhan untuk interface, kebutuhan pengontrolan serta kebutuhan database yang disesuaikan dengan pengelolaan data pasien di rumah sakit.

2. Pengembangan arsitektur informasi Emergency Health Card akan memberikan kemudahan didalam mengelola data pasien dalam melakukan proses monitoringkesehatan pasien walaupun dari rumah sakit yang berbeda-beda.

3. Sistem informasi yang tepat di dalam kegiatan pengelolaan data dan rekam medis pasien yaitu dengan menerapkan sistem informasi Emergency Health Card sehingga data dan rekam medis pasien dari rumah sakit yang berbeda-beda dapat di monitoringkesehatannya secara real time dengan terintegrasi disetiap rumah sakit dengan database berbasis cloud computing.

\section{DAFTAR PUSTAKA}

[1] Diana Aryanti, September 10, 2017, Penerapan Smartcard Pada Bidang Pelayanan Kesehatan, UNJANIMedicalStudent'sBlog, https://wadahinspirasimedstud.blogspot. co.id/2017/09/penerapan-smartcardpada-bidang.html

[2] Dicsr, Mr., Oktober 10, 2000, Unified Software Development Process (USDP), http://www.dicsrqnt.com/2016/04/unified-softwaredevelopment-process.html

[3] Fairuz, November 4, 2010, Arsitektur Sistem Informasi, Fairuzelsaid wordpress, https://fairuzelsaid.wordpress.com/2010/ 11/04/sistem-informasi-arsitekturinformasi/

[4] Firmansyah, April 30, 2018, Pengertian Cloud Computing Beserta Kelebihan,
Kekurangan dan Cara Kerja Cloud Computing, Nasabamedia, https://www.nesabamedia.com/pengertia n-cloud-computing/

[5] Ivar Jacobson, Grady Booch,James Rumbaugh, The Unified Sofware Development Process, 1999

[6] Scott W. Ambler, John Nalbone, Michael J. Vizdos, The Enterprise Unified Process: Extending the Rational Unified Process

[7] Simon Bennet, Steve McRobb and Ray Farmer, Object Oriented Systems Analysis and Design Using UML, Edisi 3. ; McGraw Hill, 2006. (SB)

[8] Wardiana, Wawan. Seminar NasionalTeknologiInformasi,Implementa siArsitektur ThreeTier PadaPelayananJasaKalibrasi,Studikasus di P2KIM LIPI,2005

[9] World Health Card, Mei 20, 2013, Emergency Health Card, Worl Healtd Card, http://www.world-healthcard.com/contents/en-us/d6 emergency-health-card.html. 
Halaman ini sengaja dikosongkan 